\title{
A past recaptured: reflections about Prospects' identity
}

\author{
Clementina Acedo
}

Published online: 27 June 2009

(C) UNESCO IBE 2009

In 1973, soon after Prospects, UNESCO's quarterly review of comparative education, began publication in Paris, Zaghloul Morsy, its editor at that time, devoted a good deal of time and effort to finding the right model for a journal corresponding to the one he envisioned. He had the idea of a unique journal with a distinctive style and identity, among the multitude of other publications on comparative education. The model that he felt most comfortable with, in terms of content and originality, was the Comparative Education Review, the prestigious American journal of comparative education, edited in the late 1970s by Philip Altbach.

The two journals started a mutually profitable "deal", with both editors having access to work on developing countries, Altbach mostly to writings by Anglo-Saxon authors, and Morsy, by virtue of his UNESCO connections, to research carried out by scholars from other developing countries. Their exchange evolved over the years into a steady co-operation and great friendship.

While Morsy was inspired by the Comparative Education Review model, he also quickly understood that Prospects could not be anything but his own conception. Brimming with energy and ideas, he invented three original features, which the journal has preserved over time. From its inception, the journal sought to identify bridges between theory and practice, between policy-makers, researchers and practitioners. This element of originality was complemented by Prospects' multi-disciplinary outlook, reflecting the diverse range of perspectives on comparative education issues, including those of anthropology, economics, environment, health, international relations, law, politics, psychology and sociology. The third original point concerned the breadth of the research published in Prospects. The journal included research on topics related to comparative education, both by well-known and by promising scholars, as long as their work was well documented and went beyond plain information or simple opinion.

What Morsy once called "une folle ambition" (Morsy 2007) became over the years one of the leading journals in the field of comparative education. The journal was first published in English and French, but soon afterwards editions in Spanish, Arabic, Russian,

C. Acedo $(\triangle)$

IBE UNESCO, P.O. Box 199, 1211 Geneva 20, Switzerland

e-mail: c.acedo@ibe.unesco.org 
Chinese, and even Bulgarian and Romanian, appeared. It grew thicker and richer, resembling a paperback book rather than a review, with issues devoted to special themes and clearly structured sections (such as Viewpoints/Controversies; Open File; Trends/ Cases; and Profiles of Educators).

In 1994, after the retirement of Zaghloul Morsy, the editorial responsibility for Prospects was transferred to the UNESCO International Bureau of Education (IBE), under the editorship of Juan Carlos Tedesco and later Jacques Hallak and Cecilia Braslavsky. In due course, the journal was taken under Kluwer Academic Publisher's (later Springer's) prestigious wing, which co-published it in English. Versions in French, Spanish, Arabic, Chinese and Russian have continued to appear, albeit irregularly. Prospects continued to mature and to influence the field of comparative education, yet its fame has wavered at times because of lack of resources and staff.

Invigorated by a new editorial team, Prospects is on the threshold of a renaissance of its own. Among many changes that are being implemented (pertaining to editorial board, editorial processes and procedures, etc.), perhaps the most important is the transformation of the publication into a peer-reviewed journal. The peer-review process includes not only the internal review of the Editorial Board, but a whole series of revisions suggested by external reviewers-distinguished scholars from all over the world.

I am pleased to recognize and encourage the new wave of research published in Prospects, whose quality is reinforced by the positive reaction of the reviewers, sometimes after two or three rounds of revisions requested of the authors. While keeping their very distinctive profiles and maintaining their own substance and identity, the paths of Prospects and the Comparative Education Review seem to intersect again.

This present issue is the first non-thematic collection of papers that was sent to external reviewers. The remarkably high standard of the current articles speaks for itself about the success of this long-awaited initiative. In this issue, we showcase research pertaining to a few topics that are at the heart of contemporary educational discourse: the commodification of higher education; the role of education in relation to the HIV and AIDS infection in SubSaharan Africa; theoretical perspectives on educational transfer; teacher policy in comparative analysis; and the innovative use of technology in education.

Globalization, neo-liberal economic policies and the growing influence of the international law on trade in services by the World Trade Organization and the General Agreement on Trade and Services have profoundly changed the well-established view of higher education as a public good. Lambasted or lauded, a new shape of public higher education emerges, which envisions education as a private good, a commodity that is subject to liberalization, privatization and commercialization. In his provocative article on "Higher education: a public good or a commodity for trade?", Jandhyala Tilak discusses the alarming effects of this shift, including commercial considerations taking over academic values, individual interests replacing social concern and purposes and short-term demands substituting long-term needs. One may read this Viewpoint as an urgent warning of the dangers lying ahead if present-day national commitments to higher education liberalization continue. A prudent course of action must be based on balancing risks against benefits and costs.

The article co-authored by David Baker, John Collins and Juan Leon is particularly revealing as it throws new light on a well-established topic in education and health studies. Public concern over the global AIDS crisis, particularly in Africa, has grown enormously in recent years. Yet, scholars and practitioners alike are still trying to grapple with the extent of this epidemic and with the role that formal school plays in its expansion and control. Based on complex statistical modeling of demographic health data, the article challenges earlier studies showing that people with higher levels of education were more 
likely to become infected with HIV than those less educated. The authors argue that the spread of accurate information on HIV and AIDS in Sub-Saharan Africa is closely linked to a lower number of young adults with more education becoming infected. Thus, the authors conclude, education acts like a sort of "social vaccine" against new infections in Africa. Schooling gives people enhanced reasoning skills that allow them to better understand the prevention strategies and the risks associated with the disease.

A new, fresh approach is also proposed by Maria Teresa Tatto in her article on teacher policy. The author argues that a teacher-focused policy should no longer be understood as a non-contextual, "politically unproblematic" matter. Instead, teacher policy studies should be fueled by a new consideration, including elements such as the changing nature of knowledge, teaching and learning in the globalization era, the governance of education systems; and the expected educational outcomes in the context of increasing worldwide economic inequities. Seeing teacher policy through the lens of a comparative framework, e.g., taking into account similarities and differences within and across regions, would provide a better understanding of the links between teacher education, teacher practice, student learning and teacher retention.

Laura Perry and Geok-hwa Tor provide a comprehensive overview of the various theoretical perspectives and conceptual frameworks necessary to understand the highly complex topic of educational transfer. They do this admirably through the pursuit of a neglected approach-namely focusing on the stages, processes and forms of educational transfer and not so much, as earlier studies have done, on its substance, agents or mechanisms.

Luis Patron, Robert Ellis and Brendan Barrett analyse Fieldtrip, a web application that enables students, professors and researchers to share their experiences and findings from real field trips virtually. The authors explore university professors' understanding and experience of Fieldtrip, while highlighting the importance of this technological innovation for learning and teaching.

This issue also includes a profile of Phillip Foster, whose remarkable work in education and development has firmly shaped the field of comparative education. A collection of essays, co-ordinated by Stephen Heyneman, and authored by N'Dri Thérèse AssiéLumumba, Janice Currie, Daniel Levy, Jeffrey M. Puryear, Stephen Heyneman and Chad Lykins, provides an impressive account of his exemplary life and scholarly work. The authors evoke the provocative and revelatory quality of his work in development, especially in Africa-among others. Foster tackled topics as diverse as tradeoffs between economic development and educational equality, human capital strategies, social mobility, educational expansion, vocational education, etc. His work, much like his personality, displayed clarity, elegance, integrity, logical rigour and grip on reality in a manner likely to stir the academic community to its depths. Yet, by reading these essays, one can be readily seduced by the affection and humanity typical of Foster, which, though not always visible to others, were abiding and profound.

Besides the fact that the articles gathered in this issue draw our attention anew to important issues that deserve more careful treatment than they have received so far, they also adduce fresh insights, while being carefully crafted, densely textured and richly perceptive. The three main guidelines set up by Zaghloul Morsy's work: "rigour, a respect for diversity, and an ever-present openness to new developments in education" (Tedesco 1997) are fully illustrated in this issue and, we hope, in all to come.

Acknowledgments My special thanks to Simona Popa for her significant contribution to the writing of this editorial. 


\section{References}

Morsy, Z. (2007). Perspectives: Genèse et évolution d'une aventure presque personnelle [Prospects: Genesis and evolution of an almost personal adventure]. LINK: Bulletin of the Association of Former UNESCO Staff Members. Available on-line at: <www.unesco.org/afus/LIEN/bHSrev1/HS_mai07.pdf >.

Tedesco, J. C. (1997). Afterword. In Z. Morsy (Ed.), Thinkers on education (Vol. 1, pp. 419-420). Paris/ New Delhi: UNESCO Publishing/Oxford \& IBH Publishing. 